\title{
小児腎不全の予防について
}

\author{
飯高 喜久雄向原茂明* 酒井糾** \\ 北里大学小児科 長崎中央病院内科* 北里大学泌尿器科**
}

(昭和 55 年 9 月 6 日受付)

Key words：小児末期腎不全, 慢性系球体腎炎, 膀胱尿管逆流, 尿管膀胱移行部の狭窄, 腎孟尿管移行部の狭窄 〈要旨〉

北里大学病院小览腎臟科に来院している患者のうち放射線学的に腎尿路系に異常の認められた 33 例について分析 を加えてみた。これらの多くの患者が精査を受けた理由は尿路感染症で，とくにVURにおける合併が多くみられた。 腎機能障害は, 片側性の腎の形態異常に腎炎を合併している者, 片側性のUPJ狭窄に他側の欠損を伴う者等にみられ た。小児腎不全の予防における小児科医の役割にまず第 1 にこの先天性尿路狭窄の早期発見, 早期治療があげられ, ついでこれらの患者における尿路感染による腎機能障害の予防があげられる。このシリーズでは, 短期間のフォロ一 アップのためニれらの患者の腎不全への進行という形ではとらえられなかったが, 腎機能障害を腎の発育という観点 からとらえてみた。VURと繰り返す尿路感染を伴う患者においては腎の発育不全がみられたが, 一方高度のUPJ狭窄 の患者においては, 尿路感染を上手にコントロールして内科的にみていくと, 腎の順調な発育が認められた。二のほ かに, 蛋白尿や高血圧のスクリーニングも無症状なニれらの患者の発見に役立っており, 高血圧のコントロールは腎 不全への進行の予防にとって大切である. 慢性系球体腎焱は小児末期腎不全の一番多い原因としてあげられているが, 腎炎の治療法には現在一定のものはなく，さまざまな治療法が試みられているが，その効果判定は不明である。

\section{Chronic renal failure in childhood}

Kikuo litaka Shigeaki Mukōbara* Tadasu Sakai**

Depertment of Pediatrics, Kitasato University School of Medicine, Depertment of Internal Medicine, Nagasaki Central Hospital*, Depertment of Urology, Kitasato University School of Medicine**

Thirty-three patients with urinary tract anomalies detected by IVP or VCG followed at Pediatric Nephrology clinic in Kitasato University Hospital were studied. Urinary tract infection was the commonest reason for the radiological investigation and was associated with VUR frequently. Impairment of renal function was observed in those who have unilateral renal anomaly with chronic glomerulonephritis and one with unilateral UPJ obstruction and agenesis of another kidney. The important roles of the pediatritian in prevention of renal failure among children are early recognition of patients with congenital obstruction of urinary tract, the referral of these patients to the urologist and prevention of the urinary tract infections which damage the renal function in them. Chronological deterioration of the renal function was not shown in these patients but failure of growth of the kidneys in patients with VUR and recurrent urinary tract infection was observed. On the other hand the normal growth of the kidneys were observed in a patient with severe UVJ obstruction whose urinary tract infections had been successfully treated medically. Screening of proteinuria and hypertension in asymptomatic children in also useful in detecting these patients with urinary tract anomalies and the control of hypertension is essential for the prevention of the development of chronic renal failure. Chronic glomerulonephritis is the commonest cause of the end stage renal diseases but there is no definitive therapy for it. Various treatments have been attempted but controlled studies are necessarry for thire evaluation. 


\section{緒言}

小児末期腎不全の原因をみると，一番多い原因として 慢性系球体腎炎があげられ，ついで腎の低形成，形成不 全抢よび尿路閉塞等の先天性腎尿路奇形，さらに慢性腎 孟腎炎があげられる1. 腎炎に対してはさまざまな治療法 が試みられているが，いまだに定まった治療法あるいは 腎不全への移行を防ぐ方法は見出されていないのが現状 である。また先天性腎尿路奇形や慢性腎孟腎炎の予防法 も見出されていないが，これらの患者において繰り返す 尿路感染による腎機能の増悪はしばしば観察され，尿路 感染症の尒防による腎機能の増悪防止が重要な課題の 1 つとなっている。

\section{目的および方法}

北里大学病院小児腎臓科に来院している患者のうち腎 尿路系に形態学的異常の認められる患者 33 例について, 精査を受けた理由, 腎尿路系の異常の種類, 程度, 腎機 能障害の有無, 尿路感染の有無, 治療抢よび長期観察例 においてはその経時的変化を調査し, 各種腎疾患よりの 腎不全への移行を予防し, その出現を遅らせるために 我々小児科医が果たしている役割について考えてみた。 尿路感染症は中間尿にて $10^{5} / \mathrm{m} l$ 以上の菌を原因菌と し，原則として 2 種類以上の菌を含まない場合とした。

\section{結果}

経静脈腎孟造影 (intravenous pyelography；IVP) 抒 よび膀胱尿道造影（voiding cystourethrography; VCG) により腎尿路系に形態学的異常の認められた患者 33 例の精査を受けた理由を表 1 にまとめてみた. 尿路感 染症が $73 \%(24 / 33)$ と一番多く, 他に腹部腫瘤, 血尿, 蛋白尿，高血圧があげられる。

これらの患者の腎尿路系の異常の種類をみてみると, 両側性あるいは片側性の膀胱尿管逆流（vesicoureteral reflux; VUR) を認めた者 14 例，尿管膀胱移行部 (ureterovesical junction; UVJ) の狭窄 4 例, 腎孟尿管 移行部 (ureteropelvic junction; UPJ) の狭窄 3 例, VUR を認めないか不明であるが, 水腎尿管症を認める者 8 例, 腎結石 2 例，尿管瘤 1 例そして神経性膀胱を伴う水腎尿 管症 2 例の合計 34 例となっている。この内 1 例は UVJ 狭窄と腎結石を合併していた(表 2)。これらの患者を尿 路感染症を伴う尿路異常を持ちVURを認めるグループ 13 例（第 1 群）と尿路感染症を伴う尿路異常を持つが VUR を認めないか不明のグループ 13 例（第 2 群）と尿 路感染症のみられない尿路異常を認めるグループ 7 例 (第 3 群）の 3 つのグループに分けて IVPとVCGの変 化, 尿路感染症の頻度と原因菌, 経過観察期間, 最近の BUN と血清クレアチニン值, 高血圧の有無抢よび精査を 受けた理由を表 $3 ， 4 ， 5$ にまとめてみた。まず尿路感

\begin{tabular}{lr}
\hline urinary tract infection & 20 \\
urinary tract infection with other anomalies & 2 \\
urinary tract infection with renal calculus & 2 \\
\cline { 2 - 2 } & 24 \\
abdominal tumor & 3 \\
hematuria & 2 \\
Proteinuria & 1 \\
abdominal pain and fever & 2 \\
hypertension & 1 \\
\\
* one patient with meningomyelocele and one with anal \\
atresia
\end{tabular}

表| The reasons for the rediological investigations in 33 patients with anomalies of urinary tract

\begin{tabular}{lc}
\hline Vesicoureteral reflux (VUR) & 14 \\
Ureterovesical junction obstruction & $4^{*}$ \\
Ureteropelvic junction obstruction & 3 \\
Hydronephroureter (VUR none or unknown) & 8 \\
Renal calculi & $2^{*}$ \\
Ureterocele & 1 \\
Neurogenic bladder and hydronephroureter & 2 \\
& Total \\
$*$ one patient has both UVJ obstruction and renal calculi
\end{tabular}

表 2 Anomalies of urinary tract

染症を伴う尿路異常のうち VUR を認めたI 群をみてみ ると, 男子 3 例, 女子 10 例で, IVPにて腎実質, 腎盃の 変化を 12 例に認め, 尿管のみの変化を 1 例に認めた(表 $3)$. 両側性の変化は 8 例に片側性の変化は 5 例に認めら れた、VCGにおけるVURの程度の分類如図1に示され る様に grade IよりIVまでの4 段階に分けられた2! grade III以上の変化を示した患者は 9 例. II 以下が 4 例 みられた。片側性 VURのみられた 4 例（症例 $3 ， 7 ， 8$ ， 13）のうちIVPにて腎および腎盃の変化が認められた同 側にのみVURのみられた者は 3 例で, もう1例（症例 8 ）はIVPにて両側性の遠位部尿管の拡張のみを示し, VCGにて右側に Grade I D VUR を認めたにすぎず， 腎実質, 腎盃の変化はみられなかった。尿路感染症の原 因菌は表 3 に示されている様に, E. Coli, Klebsiella 菌に 多く,この他に pseudomonas aeruginosa, serratia, staphylococcus epidermidis, enterobacter 等の opportunistic infectionがその主なものとなっている。治療は 一般的に培養された菌が感受性を認める抗生物質を 10 から 14 日間経口投与し, 尿培養が陰性になった後投薬中 


\begin{tabular}{|c|c|c|c|c|c|c|c|c|c|c|c|}
\hline No & $\mathrm{Pt}$ & $\begin{array}{l}\text { Age } \\
(y)\end{array}$ & Sex & $\begin{array}{l}\text { Radiological fin } \\
\text { IVP }\end{array}$ & $\begin{array}{l}\text { ndings } \\
\text { VCG(grade) }\end{array}$ & $\begin{array}{r}\text { Bacterial infect } \\
\mathrm{fr}\end{array}$ & $\begin{array}{l}\text { tion } \\
\text { req }\end{array}$ & $\begin{array}{l}\text { follow-up } \\
\operatorname{period}(y)\end{array}$ & $\begin{array}{l}\text { BUN creat } \\
\mathrm{mg} / \mathrm{dl}\end{array}$ & HBP & $\begin{array}{l}\text { reason for work up } \\
\quad \& \text { comments }\end{array}$ \\
\hline 1 & & 3 & $\mathrm{M}$ & $\begin{array}{l}\text { Rt: cortex thinning } \\
\mathrm{Lt} \text { : cortex thinning } \\
\text { hydronephrosis }\end{array}$ & $\begin{array}{l}\text { Rt: II VUR } \\
\text { Lt: III V }\end{array}$ & $\begin{array}{l}\text { Pseudomonas } \\
\text { aeruginosa } \\
\text { serratia }\end{array}$ & 2 & $<1$ & $32 / 0.9$ & - & \\
\hline 2 & & 6 & $\mathrm{M}$ & $\begin{array}{l}\text { Rt: two lobulation } \\
\text { pelvic deformity } \\
\text { Lt: small kidney }\end{array}$ & bilat: III & staph. epi & 2 & 1 & $15 / 0.9$ & - & recurrent UTI \\
\hline 3 & & 14 & M & $\begin{array}{l}\text { Rt: atrophic kidney } \\
\text { Lt: WNL }\end{array}$ & $\begin{array}{l}\text { Rt: II } \\
\text { Lt: WNL }\end{array}$ & $\begin{array}{l}\text { E. coli } \\
\text { klebsiela }\end{array}$ & 2 & 9 & $31 / 2.1$ & - & $\begin{array}{l}\text { UTI } \\
\text { abnormal renogram }\end{array}$ \\
\hline 4 & & 2 & $\mathrm{~F}$ & $\begin{array}{l}\text { Rt: WNL } \\
\text { Lt: hydronephrosis }\end{array}$ & bilat: III & unknown & 3 & 3 & & - & recurrent UTI \\
\hline 5 & & 4 & $\mathrm{~F}$ & $\begin{aligned} \text { bilat: } & \text { cortex thinning } \\
& \text { blunt calyces }\end{aligned}$ & $\begin{array}{l}\text { Rt: III } \\
\text { Lt: II }\end{array}$ & E. coli & 3 & $<1$ & & - & recurrent UTI \\
\hline 6 & & 4 & F & $\begin{array}{c}\text { bilat: hydronephro- } \\
\text { ureter }\end{array}$ & bilat: III & E. coli & 3 & 3 & $11 / 0.6$ & - & recurrent UTI \\
\hline 7 & & 6 & $\mathrm{~F}$ & $\begin{array}{l}\text { Rt: cortex thinning } \\
\text { Rt: WNL } \\
\text { Lt: moderate hydro- } \\
\text { nephrosis }\end{array}$ & $\begin{array}{l}\text { Rt: WNL } \\
\text { Lt: } I I I \sim I V\end{array}$ & $\begin{array}{l}\text { E. coli } \\
\text { staph. epi }\end{array}$ & 4 & 3 & $7 / 0.4$ & - & $\begin{array}{l}\text { recurrent UTI } \\
\text { post ope Lt uretero } \\
\text { neocystostomy }\end{array}$ \\
\hline 8 & & 8 & F & $\begin{array}{l}\text { bilat: distal ureter } \\
\text { dilatation }\end{array}$ & $\begin{array}{l}\text { Rt: I } \\
\text { Lt: WNL }\end{array}$ & E. coli & 9 & 3 & $15 / 0.6$ & - & recurrent UTI \\
\hline 9 & & 9 & F & $\begin{aligned} \text { Rt: } & \text { calyces \& upper } \\
& \text { ureter dilatation } \\
& \text { blunt calyces } \\
\text { Lt: } & \text { WNL }\end{aligned}$ & bilat: III & $\begin{array}{l}\text { E. coli } \\
\text { klebsiella }\end{array}$ & 4 & $<1$ & $15 / 0.5$ & - & recurrent UTI \\
\hline 10 & & 9 & $\mathrm{~F}$ & $\begin{array}{l}\text { bilat: small kidney } \\
\text { Rt: lower ureter } \\
\text { dilatation } \\
\text { Lt: hydroureter }\end{array}$ & $\begin{array}{l}\text { Rt: II } \\
\text { Lt: II III }\end{array}$ & E. coli & 3 & 1 & $10 / 0.5$ & - & recurrent UTI \\
\hline 11 & & 10 & $\mathrm{~F}$ & $\begin{aligned} \text { bilat: } & \text { hydronephro- } \\
& \text { ureter \& } \\
& \text { cortex thinning }\end{aligned}$ & bilat: II III & $\begin{array}{l}\text { enterobacter } \\
\text { E. coli } \\
\text { klebsiella }\end{array}$ & 12 & 6 & $26 / 1.2$ & - & $\begin{array}{l}\text { recurrent UTI } \\
\text { abnormal renogram }\end{array}$ \\
\hline 12 & & 13 & $\mathrm{~F}$ & $\left.\begin{array}{rl}\text { '72 Rt: } & \text { WNL } \\
\mathrm{Lt}: & \text { blunt calyces } \\
& \text { of upper pole } \\
\text { '75 Rt: } & \text { blunt calyces } \\
\text { '78 } & \text { of upper pole } \\
& \text { partial cortex } \\
& \text { thinning } \\
\text { Lt: } & \text { distal ureter } \\
& \text { dilatation }\end{array}\right]$ & $\begin{array}{l}\left.\text { '72 } \begin{array}{ll}\text { Rt: II } \\
\text { Lt: I } \\
\text { '73 } \text { bilat: II } \\
\text { '74 } & \text { Rt: II } \\
\text { '78 } & \text { Lt: WNL }\end{array}\right] \\
\\
\end{array}$ & $\begin{array}{l}\text { klebsiella } \\
\text { E. coli }\end{array}$ & 6 & 7 & $16 / 0.5$ & - & $\begin{array}{l}\text { recurrent UTI } \\
\text { no growth of } \\
\text { Rt kidney }\end{array}$ \\
\hline 13 & & 14 & $\mathrm{~F}$ & $\begin{aligned} \text { Rt: } & \text { WNL } \\
\text { Lt: } & \text { blunt calyx } \\
& \text { of middle kidney, } \\
& \text { distal ureter } \\
& \text { dilatation }\end{aligned}$ & $\begin{array}{l}\text { Rt: WNL } \\
\text { Lt: II }\end{array}$ & unknown & 2 & 5 & $13 / 0.3$ & - & recurrent UTI \\
\hline
\end{tabular}

表 3 Patients with infection and anomaly of urinary tract with vesicoureteral reflux (Group I)

止あるいはサルファ剂，ナリジクス酸阂またはST 合剤 の数か月から数年の長期少量予防投与が行なわれている. 予防効果は一般に良好で, 感染の再発は大部分予防薬の 投与中止後または服薬が守られていない場合に発症した 例が多く認められている。経過観察期間は発症より数か 月から 9 年までで高血圧は 1 例もみられなかったが, 13 例中 2 例(症例 3,11 )にBUN 抢よびクレアチニン值の上
昇が認められた。症例 3 においては繰り返す肉眼的血尿 および腎機能低下が認められ，IVPにて右腎は萎縮し， 左腎はほぼ正常範囲内であり，左腎の腎生検にてメサン ギウムの増殖を認めた。この患児は 2 度尿路感染症を起こ しているが, 右腎のみの変化では機能障害は説明し難く, 右腎の形成不全およびVURに慢性系球体腎炎が加味し, 腎機能障害を起こしてきたと推測される。症例 11 は 4 


\begin{tabular}{|c|c|c|c|c|c|c|c|c|c|c|c|}
\hline No & $\mathrm{Pt}$ & $\begin{array}{c}\text { Age } \\
(\mathrm{y})\end{array}$ & Sex & $\begin{array}{l}\text { Radiological finding } \\
\text { IVP }\end{array}$ & VCG (grade) & Bacterial infec & $\begin{array}{l}\text { tion } \\
\text { freq }\end{array}$ & $\begin{array}{l}\text { follow-up } \\
\operatorname{period}(y)\end{array}$ & $\begin{array}{l}\text { BUN creat } \\
\mathrm{mg} / \mathrm{dl}\end{array}$ & HBP & $\begin{array}{l}\text { reason for work up } \\
\& \text { comments }\end{array}$ \\
\hline 1 & & 1 & M & $\begin{aligned} & \text { bilat: } \text { severe hydronephro- } \\
& \text { ureter }(\mathrm{Rt}>\mathrm{Lt}) \text { and } \\
& \text { UVJ obstruction } \\
& \text { elevated bladder base }\end{aligned}$ & e & $\begin{array}{l}\text { E. coli } \\
\text { serratia } \\
\text { pseudomonas } \\
\text { aeruginosa }\end{array}$ & cont & 1 & $14 / 0.4$ & - & $\begin{array}{l}\text { post ope atresia ani } \\
\text { (neurogenic bladder) } \\
\text { TOF UTI }\end{array}$ \\
\hline 2 & & 1 & M & $\begin{aligned} \text { Rt: } & \text { WNL } \\
\text { Lt: } & \text { renal stones \& UVJ } \\
& \text { obstruction }\end{aligned}$ & ND & $\begin{array}{l}\text { citrobacter } \\
\text { staph. epi } \\
\text { E. coli } \\
\text { ascineto } \\
\text { proteus } \\
\quad \text { mirabilis }\end{array}$ & cont & $<1$ & $11 / 0.4$ & - & $\begin{array}{l}\text { cloudy urine \& } \\
\text { stone } \\
\text { (mixed infection) }\end{array}$ \\
\hline 3 & & 3 & M & $\begin{array}{l}\text { bilat: blat calyces of } \\
\text { upper pole } \\
\text { Lt: slight hydronephrosis }\end{array}$ & ND & $\begin{array}{l}\text { proteus } \\
\text { mirabilis }\end{array}$ & 2 & 1 & & - & recurrent UTI \\
\hline 4 & & 7 & M & $\begin{array}{l}\text { Rt: blunt calyces of } \\
\quad \text { upper pole } \\
\text { Lt: hydronephroureter }\end{array}$ & ND & unknown & $\begin{array}{l}1 \\
(?)\end{array}$ & 3 & $14 / 0.5$ & - & UTI \\
\hline 5 & & 7 & M & $\begin{array}{l}\text { bilat: hydronephroureter } \\
\text { and UVJ obstruction }\end{array}$ & WNL & $\begin{array}{l}\text { proteus } \\
\text { mirabilis } \\
\text { E. coli }\end{array}$ & 3 & 6 & $19 / 0.4$ & - & UTI \\
\hline 6 & & 7 & M & $\begin{aligned} \text { Rt: } & \text { compensatory hyper- } \\
& \text { trophy } \\
\text { Lt: } & \text { renal stone and } \\
& \text { atrophic kidney }\end{aligned}$ & ND & unknown & cont & 2 & & - & $\begin{array}{l}\text { recurrent UTI } \\
\text { follow up at other } \\
\text { hospital }\end{array}$ \\
\hline 7 & & 14 & M & $\begin{array}{l}\text { Rt: calyectasis } \\
\text { Lt: hydronephrosis }\end{array}$ & ND & unknown & $\begin{array}{c}1 \\
(?)\end{array}$ & 3 & $49 / 2.9$ & - & $\begin{array}{l}\text { hematuria } \\
\text { CGN }\end{array}$ \\
\hline 8 & & 15 & M & bilat: hydronephroureter & $\begin{array}{l}\text { pine tree } \\
\text { bladder } \\
\text { no VUR }\end{array}$ & $\begin{array}{l}\text { pseudomonas } \\
\text { aeruginosa } \\
\& \text { other mixed } \\
\text { infections }\end{array}$ & cont & 4 & $18 / 1.0$ & - & $\begin{array}{l}\text { UTI \& meningomyelocele } \\
\text { neurogenic bladder } \\
\text { no foreign body }\end{array}$ \\
\hline 9 & & 4 & $\mathrm{~F}$ & $\begin{aligned} \text { Rt: } & \text { WNL } \\
\text { Lt: } & \text { slight hydronephrosis } \\
& \& \text { distal hydroureter }\end{aligned}$ & ND & unknown & $\begin{array}{l}1 \\
(?)\end{array}$ & 1 & & - & fever \& proteinuria \\
\hline 10 & & 4 & F & $\begin{array}{l}\text { bilat: double collecting } \\
\text { system* } \\
\text { Rt: hypertrophic kidney } \\
\text { Lt: atrophic kidney }\end{array}$ & WNL & $\begin{array}{l}\text { strept. } \\
\text { fecalis }\end{array}$ & 2 & 1 & $18 / 1.0$ & - & $\begin{array}{l}\text { recurrent UTI } \\
\text { *bilat: blunt calyces of } \\
\text { lower pole }\end{array}$ \\
\hline 11 & & 6 & $\mathrm{~F}$ & $\begin{array}{l}\text { Rt: distal hydroureter } \\
\text { Lt: severe hydronephro- } \\
\text { ureter } \\
\text { UVJ obstruction }\end{array}$ & ND & $\begin{array}{l}\text { E. coli } \\
\text { proteus } \\
\text { mirabilis } \\
\text { pseudomonas } \\
\text { aeruginosa } \\
\text { klebsiella }\end{array}$ & 5 & 3 & $11 / 1.0$ & - & $\begin{array}{l}\text { recurrent UTI } \\
\text { '78.7 Lt: uretero- } \\
\text { neocystostomy } \\
\text { '78.11 nephrourete- } \\
\text { rectomy }\end{array}$ \\
\hline 12 & & 6 & $\mathrm{~F}$ & $\begin{array}{l}\text { Rt: blunt calyces of } \\
\quad \text { upper pole } \\
\text { Lt: WNL }\end{array}$ & $\begin{array}{l}\text { WNL } \\
\text { (residual } \\
\text { urine) }\end{array}$ & $\begin{array}{l}\text { E. coli } \\
\text { proteus } \\
\text { mirabilis }\end{array}$ & 5 & 2 & $9 / 0.5$ & - & recurrent UTI \\
\hline 13 & & 8 & $\mathrm{~F}$ & $\begin{aligned} \text { Rt: } & \text { WNL } \\
\text { Lt: } & \text { slightly blunt } \\
& \text { calyces and stasis }\end{aligned}$ & ND & E. coli & 3 & 1 & $12 / 0.6$ & - & recurrent UTI \\
\hline
\end{tabular}

表 4 Patients with infection and anomaly of urinary tract (Group II)

才より10 回程尿路感染症を繰り返している 10 才の女子 で, 来院時すでにIVPにて慢性腎孟腎炎の所見を示して おり，VCGにて両側性の grade II〜IIIのVURがみら れ，腎機能低下を認めていた。この変化が尿路感染症と VURによる 2 次性の変化か, 腎形成不全とVURが先天
的にあり，これに尿路感染が加わって起きてきた変化か は不明であるが，腎形成不全とVURの高頻度の合併率 を考え, 後者にあたる例がかなりあるのではないかと考 えられる。

1972 年より 7 年間にわたり長期経過観察されている 


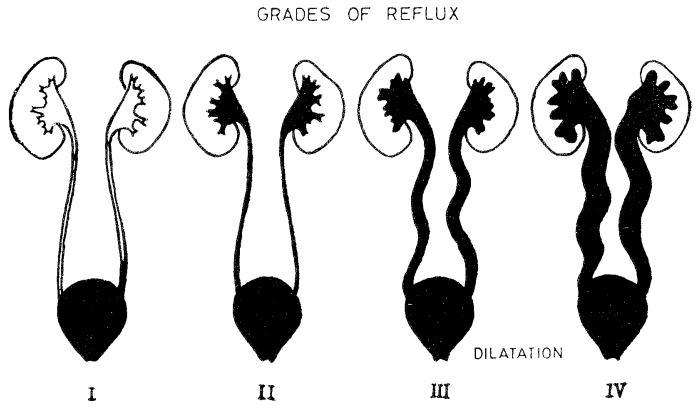

図 I Grades of vesicoureteral reflux

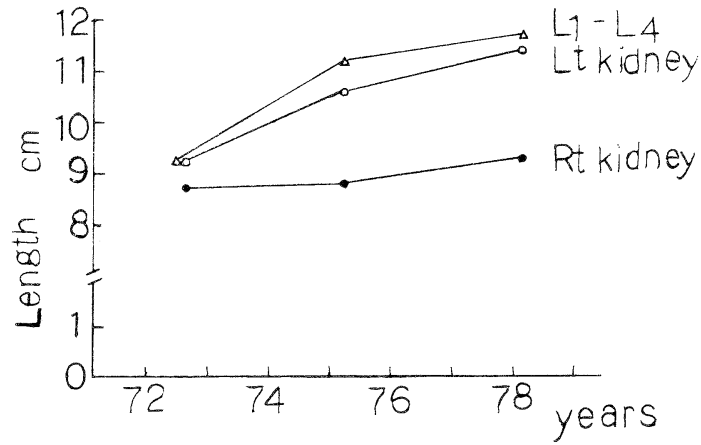

図 2 Growth of kidneys and lumber vertebrae (L1-4) by IVP in patient 12 (

\begin{tabular}{|c|c|c|c|c|c|c|c|c|c|c|c|}
\hline \multirow[t]{2}{*}{ No } & \multirow[t]{2}{*}{$\mathrm{Pt}$} & \multirow{2}{*}{$\begin{array}{r}\text { Age } \\
(\mathrm{y})\end{array}$} & \multirow[t]{2}{*}{ Sex } & \multicolumn{2}{|c|}{ Radiological findings } & \multicolumn{2}{|c|}{ Bacterial infection } & \multirow{2}{*}{$\begin{array}{l}\text { follow-up } \\
\operatorname{period}(y)\end{array}$} & \multirow{2}{*}{$\begin{array}{l}\text { BUN creat } \\
\mathrm{mg} / \mathrm{dl}\end{array}$} & \multirow[t]{2}{*}{ HBP } & \multirow{2}{*}{$\begin{array}{l}\text { reason for work up } \\
\& \text { comments }\end{array}$} \\
\hline & & & & IVP & VCG(grade) & & freq & & & & \\
\hline 1 & & 3 & M & $\begin{array}{l}\text { Rt: absent kidney } \\
\text { Lt: UPJ obstruction }\end{array}$ & WNL & $\begin{array}{r}\text { pseudomonas } \\
\text { aeroginosa }\end{array}$ & 1 * & $<1$ & $27 / 1.2$ & - & $\begin{array}{l}\text { polyuria \& abdominal mass } \\
779.9 .27 \text { pyeloplasty }\end{array}$ \\
\hline 2 & & 6 & M & $\begin{array}{l}\text { '78.2 WNL } \\
\text { '79.4 Rt: WNL } \\
\text { Lt: } \text { slight hydro- } \\
\text { ureter \& blunt } \\
\text { calyces of upper } \\
\text { pole }\end{array}$ & $\begin{array}{l}\text { ND } \\
\text { ND }\end{array}$ & neg & 0 & 3 & $11 / 0.4$ & - & $\begin{array}{l}\text { abdominal pain and } \\
\text { fever }\end{array}$ \\
\hline 3 & & 10 & $\mathrm{M}$ & $\begin{aligned} \text { Rt: } & \text { WNL } \\
\text { Lt: } & \text { severe hydro- } \\
& \text { nephrosis due to } \\
& \text { UPJ obstruction }\end{aligned}$ & ND & neg & 0 & 1 & $18 / 0.5$ & - & $\begin{array}{l}\text { abdominal pain } \& \\
\text { abdominal mass } \\
\text { ' } 80.1 \text { ope }\end{array}$ \\
\hline 4 & & 12 & M & $\begin{array}{l}\text { bilat: severe hydronephro- } \\
\text { ureters and thin } \\
\text { cortex }\end{array}$ & $\begin{aligned} \text { bilat: } & \text { severe } \\
& \text { VUR IV }\end{aligned}$ & neg & 0 & 1 & $17 / 0.8$ & + & $\begin{array}{l}\text { asymptomatic } \\
\text { hypertension }\end{array}$ \\
\hline 5 & & 4 & F & $\begin{array}{l}\text { Rt: WNL } \\
\text { Lt: severe hydronephrosis }\end{array}$ & WNL & neg & 0 & 2 & $20 / 0.3$ & - & $\begin{array}{l}\text { fever and } \\
\text { abdominal mass }\end{array}$ \\
\hline 6 & & 5 & $\mathrm{~F}$ & $\begin{aligned} \text { Rt: } & \text { double collecting } \\
& \text { system \& hydro- } \\
& \text { nephrosis due to } \\
& \text { ureterocele }\end{aligned}$ & ND & neg & 0 & 2 & $18 / 0.3$ & - & $\begin{array}{l}\text { fever and dysuria } \\
\text { hematuria }\end{array}$ \\
\hline 7 & & post & ope & $\begin{array}{l}\text { Rt: WNL } \\
\text { Lt: hydronephrosis due to } \\
\quad \text { UPJ obstruction }\end{array}$ & WNL & neg & 0 & $<1$ & $10 / 0.7$ & - & $\begin{array}{l}\text { fever, nausea } \\
\text { abdominal pain } \\
\text { '79. } 12 \text { post ope } \\
\text { Lt: pyeloplasty }\end{array}$ \\
\hline
\end{tabular}

表 5 Patients with anomaly of urinary tract without infection (Group III)

症例 12 は 13 歳の女子で, 不明の発熱, 白血球尿を繰り 返すため本院入院となり，入院時尿培養にて Klebsiella 菌 $10^{5} / \mathrm{ml}$ が認められ, IVPにて左腎上極の腎盃の鈍化 がみられたが, 右腎は特に異常はみられなかった（写真 1 A). VCGにて右 grade II, 左 grade I の両側性 VUR 在認めた。2 年後のVCGにて左VURは消失したが, 右 VURは 78 年まで持続した. 3 年後の IVPにて右腎上極 の腎盃の拡張, 腎実質の皮薄化の進行がみられた（写真 (B). 左腎の変化はみられなかった.そしてこの 6 年間
に計 6 回の尿路感染症が記録されている。VURの持続 と尿路感染症を繰り返す患者における腎病変の進行が観 察されたが，この患者の腎蔵の発育をIVP上の大きさで 調べてみると, 図 2 に示されるごとく, 左腎に比し右腎 の発育不良が明瞭に認められる.

次に尿路感染症を伴う尿路異常で, VURがみられな いか, あるいは不明の第 2 群 13 例についてみてみると, 男子 8 例, 女子 5 例で, 全例にIVP 上腎実質および腎盃 の変化が認められた(表 5 )。両側性の変化は 7 例に, 片 


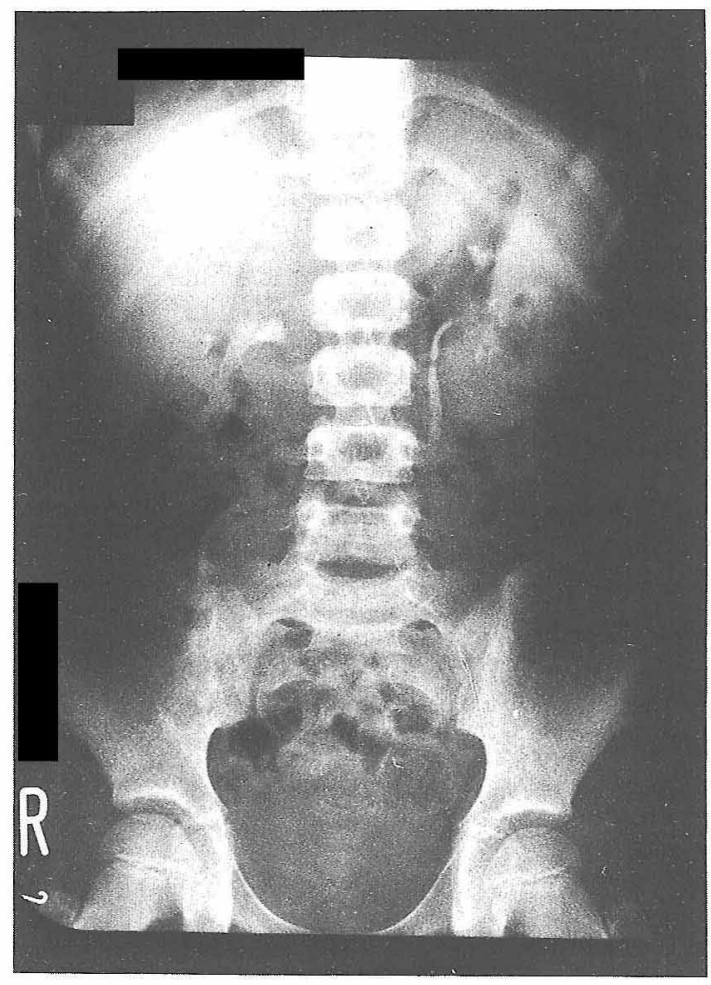

A

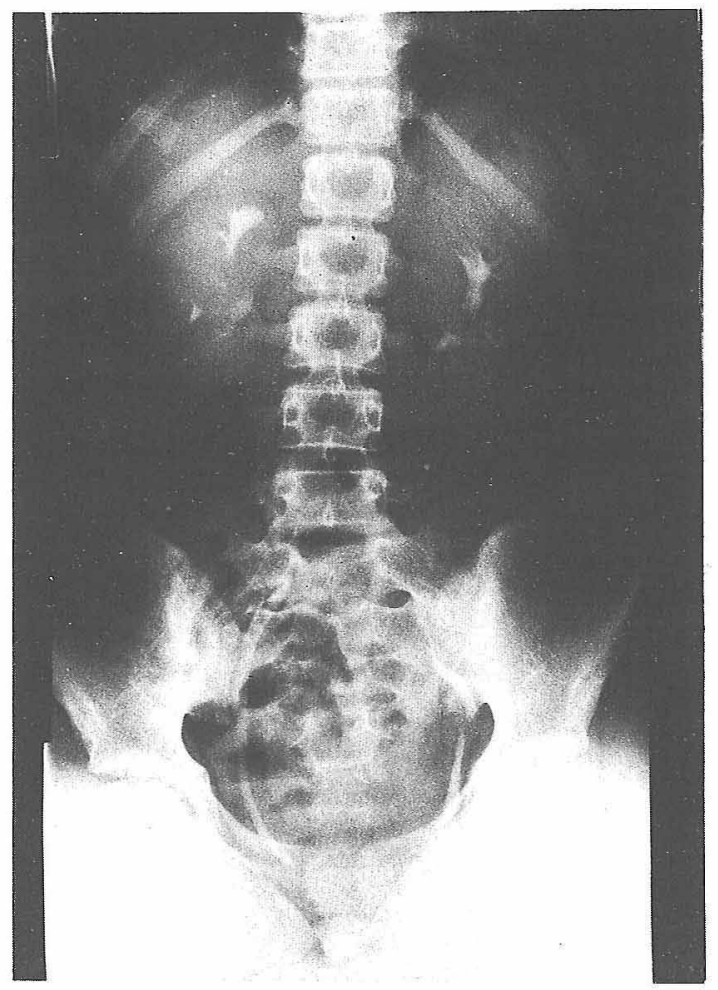

B

写真 I IVP of patient $12(\quad)$ in group I in $1972(\mathrm{~A})$ and 1978 (B)

側性の変化は 6 例にみられ，尿管膀胱移行部 (UVJ) の 狭窄と思われる患者が 4 例，腎結石の患者が 2 例（この 内 1 名はUVJ 狭窄を認めている), 髄膜雨髄瘤のため神 経性膀腅を持つ患者が 1 例，惄実質および腎盃の変化は あるが，VCG未施行のためVURの有無が不明の者 5 例，そして腎盃の変化を認めるもVURのみられない者 2 例となっている。尿路感染の原因菌はやはり $\mathrm{E}$ ，Coli， Proteus 菌の他に弱毒菌が多くみられ，特に結石を伴う 場合 (症例 2,6 ), 䯣膜䨐髄瘤の患者 (症例 8), 鎖肛 の手術後でやはり神経性膀胱を持つUVJ狭窄の患者 （症例 1 ）の 4 人の患者は慢性の持続性の尿路感染症を 併発している。症例 1 はファローの四微症 (TOF) およ び鎖肛術後の患者で, 生後 I か月目の IVPにて両側性の UVJ 狭寉，右の腎盃，腎盂打よび尿管の極度の拡張がみ られ，左腎は此較的正常に保たれていたが，1年 4 か月 後のIVPにて右の水腎尿管および左腎の腎盃, 腎跙, 尿 管の変化の進行が認められた。この間主として serratia の持続感染がみられるも各種抗生剂に反応しないか，反 応がみられても投与中止後ただちに再燃するため，現在 は治療せずに経過観察しているが，無症状に経過してい
る。症例 11 林 6 歳の女子で, 再発性尿路感染症のため IVPによる精査を受け，左側のUVJ 㹨窄による水腎尿 管が認められた症例で, 78 年 7 月左側の尿管膀腅吻合が 行われたが, 手術部位の感染のため同年 11 月左側腎尿管 の摘出が行われた。症例 5 は, 現在 7 歳の男子で, 生後 5 か月時に白血球尿が認められ，尿培養により尿路感染 症の診断がつけられ，以後 6 年以上フォローされている 症例である。生後 5 か月目に施行されたIVPにて極度に 拡張した両側の腎盃，尿管が認められたがVURはみら れず,UVJの狭窄によるものと思われた(写真 $2 \mathrm{~A}$ )。以後 内科的に経過を観察していくと,UVJ の狭窄は依然とし てみられるものの，腎盃，覀管の変化は改善を示してき ており,腎実質の厚さも $1.3 \mathrm{~cm}$ となってきている(写真 2 B). 尿路感染は 6 年間に 3 回みられたのみで, 非常に良 く管理されており，最近 3 年間は予防的抗生㓮の投与も されずにいるが，尿路感染も起こさずに順調に経過して いる。腎臟の発育も図 3 に示されるごとく順調に発育し ている。第 2 群の患者の中にはやはり高血圧を認めた者 はなく、BUNとクレアチニン值の上昇を認めた者は 1 例であった。症例 7 は左の水腎尿管㧍よび右の腎盃の変 
化を認めたが，书生検により慢性系球体腎炎の合併が確 認されており，腎機能の低下は腎炎の合併によるものと 考えられている。症例 8 は䯣膜脊髄瘤による神経性膀胱 を持ち,持続性の尿路感染症を起こしている患者である。 症例 10 はIVPにて左の萎縮腎，右腎下極の腎盃の変形 を認め, VUR はなく，尿路感染を 2 度認めている。症例 11 は先に述べた患者で，この症例 8，10，11の3 例は $\mathrm{BUN}$ が 11〜 $18 \mathrm{mg} / \mathrm{dl}$ を示しているが, クレアチニン 值は $1.0 \mathrm{mg} / \mathrm{dl}$ とやや高值を示している。

第 3 群の尿路感染症を伴わない腎尿路系の異常を持つ 患者は男子 4 例，女子 3 例よりなる。IVP施行理由は， 腹部腫瘤 3 例，発熱㧍よび腹痛 2 例，発熱扝よび排疗痛 1 例，高血圧 1 例となっている。IVP の所見にて，腎孟

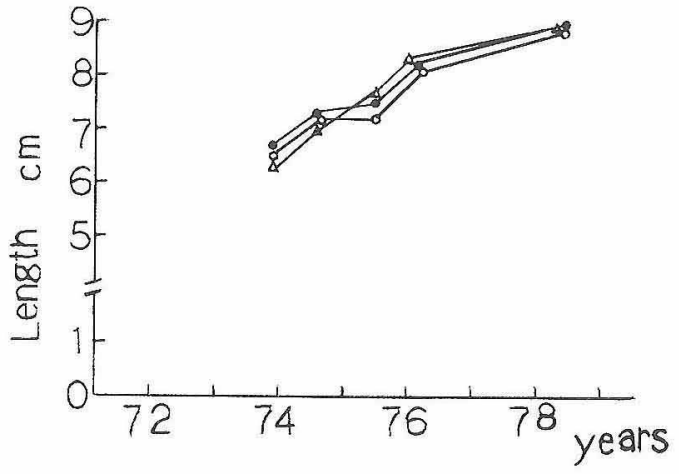

図 3 Growth of kidneys and lumber vertebrae (L1.4) by IVP in patient $5(-)$ (see Fig. 3)

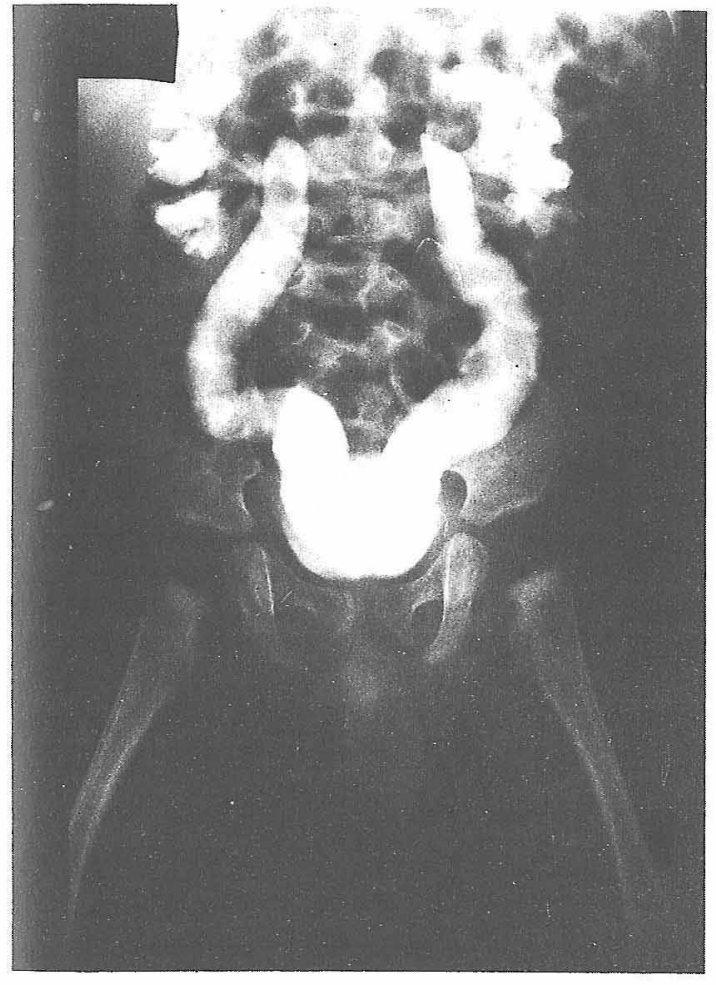

A

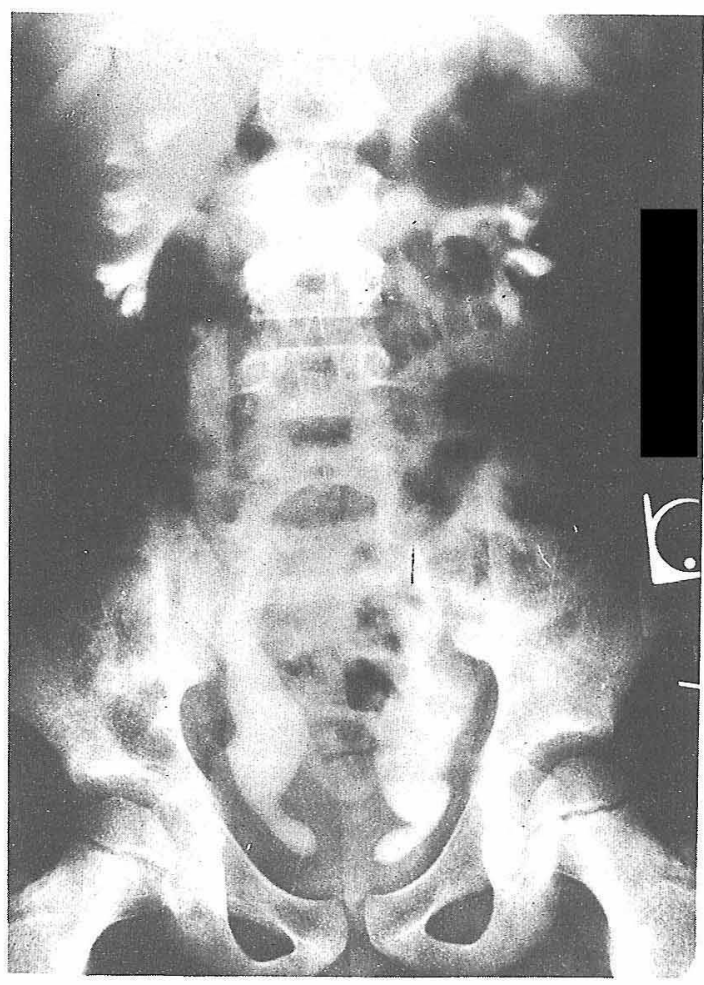

B

写真 2 IVP of patient 5 ( ) in group II in $1973(\mathrm{~A})$ and $1978(\mathrm{~B})$

尿管移行部 (UPJ) の狭䆻が 4 例，高度のVUR 1 例，尿 管瘤 1 例, VUR 不明の水甭症 1 例がみられた。両側性の 変化を示した患者は 2 例で，片側性は 5 例であった。片 側性 UPJ 狭窄の 4 例（症例 1，3，5，7）は全例狭窟 部の手術（pyeloplasty）を受けたか，近々受ける予定と なっている。BUN およびクレアチニン值の上舁を認め た症例 1 は，13 歳の男子で右腎の欠損に左腎のUPJ 狭
窄を合併したため，瞋機能障害を起こしてきたものと考 えられ，術前，尿路感染症の既応はみられなかった。症 例 4 は手の骨折にて入院時，たまたま高度の高血圧 $240 /$ $180 \mathrm{mmHg}$ 学指摘された 12 歳男子で, 骨折部以外は全 く無症状であったが，間歇的に蛋白尿が認められた。 VCGにて両側性の高度のVUR が見出された(写真 3 )。 降圧剂による血圧のコントロール後, 腎血管造影にて腎 


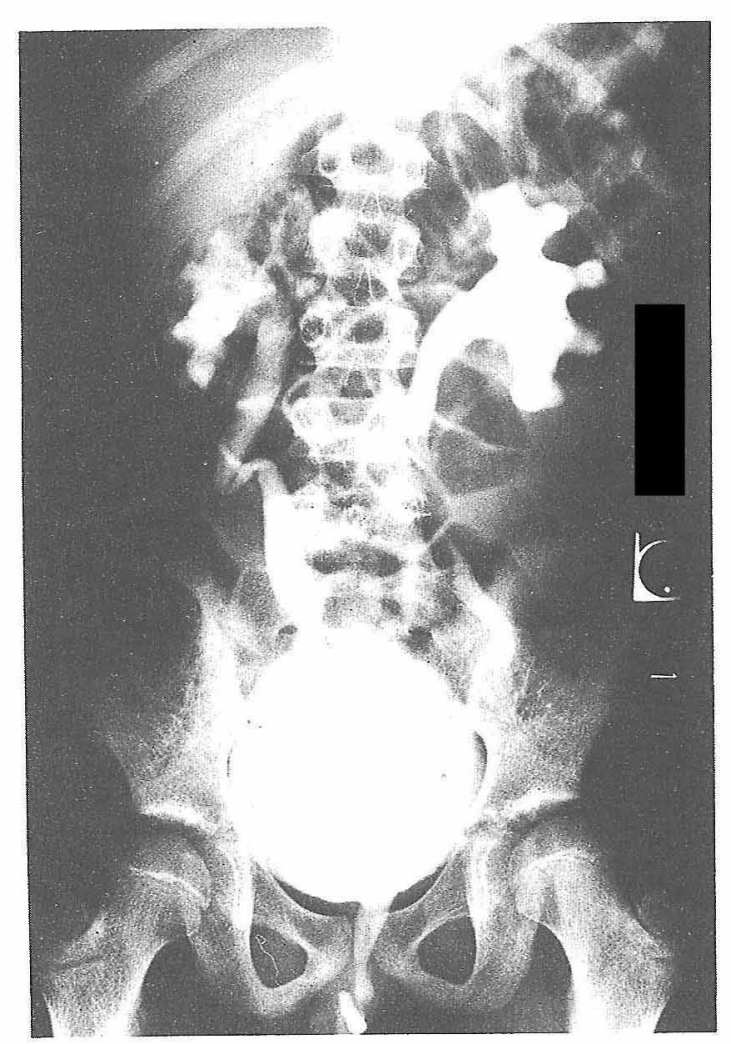

写真 3 VCG of patient 4 (HM) in group III showing severe VUR

血管の狭窄のないことを確認し，両側の尿管膀胱吻合術 が施行された。経過をみると患者の高血圧は大量のヒド ララジン，メチルドーパ，利尿剂投与に対する反応はあ まりみられず,少量のプロプラノロールによく反応した。 さらに逆流防止術施行後さらに血圧は安定し, 降圧抄の 減量が可能となってきている(図 4)。

\section{考察および結論}

小児腎不全の予防に括ける小巟科医の役割として，ま ず後部尿道弁や尿管狭窄等の先天性尿路閉塞性疾患の早 期診断があげられる。腎機能障害の進行しない時期にこ れらの狭窄に対する治療が行われる様に泌尿器科の医師 への依頼に努めることで，これには乳児の定期検診にお ける成長発育の千ェック，飲水量，尿量および尿線の確 認，腹部の触診が大切なポイントとなる。また以上述べ たデーターよりも明らかな様に，これらの患者と尿路感 染症の合併は多くみられ，尿路感染症を認めた患者にお けるIVPや VCGによる放射線検査により，腎尿路系の 異常をみつけ出し，尿路感染の予防や早期治療を心掛け ることも小児科医の大切な役割である。このためこれら

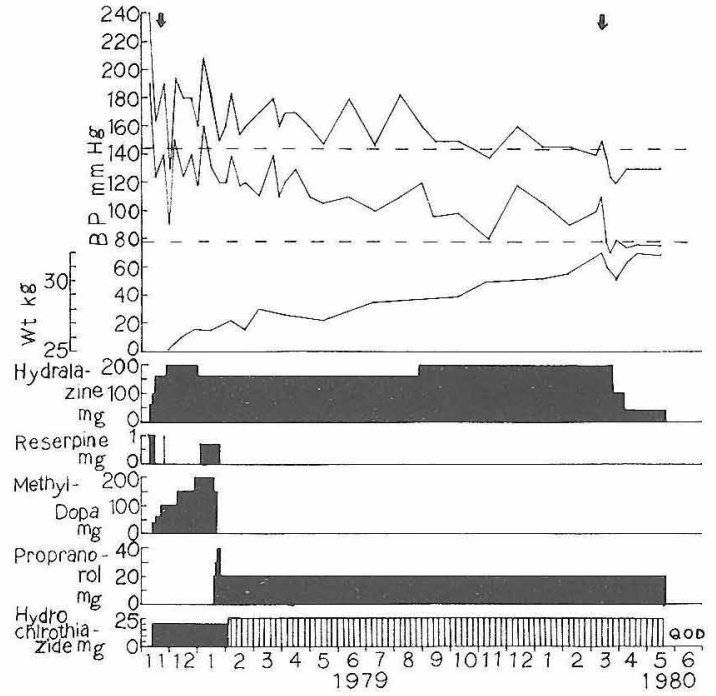

图 4 Clinical course of patient 4()

の患者に対し，抗生剤の長期少量予防投与が行われるこ とが多い。ここで，我々の行っている尿路感染症におけ るIVPによる精査の基準について述べてみると，男子お よび乳幼児女子では初回の尿路感染，年長女子では 2 回 以上繰り返す尿路感染を起こしている患者にIVPによ る検索を行っている。現在我々はIVPにて異常の認めら れた場合に感染後 6 週間以上経過してから VCGを行う 方針をとっているが，IVPにて正常の場合にもVURが 認められる場合もあり得るので注意を要するが，高度の VURを伴う場合はかならずIVPにてなんらかの変化を 認めると思われる。これらの精査により発見された蜸尿 路の異常は表 2 にまとめられているが，VURを持つ患 者には尿路感染の合併が多くみられ，反対にUPJ 狭窄等 高位㽷路閉塞持つ患者には尿路感染の合併は認められ なかった。これらの患者に括いて血清クレアチニン值 1 . $0 \mathrm{mg} / \mathrm{dl}$ 以上を示した患者をみてみると,片側性の形態 学的異常に腎炎の合併の認められる者 2 例, 両側性 VUR と再発性尿路感染症を認める慢性腎需腎炎患者 2 例，髄膜春髄瘤による神経性膀胱のための持続性尿路感 染症を伴う者 1 例，片側性の尿路狭窄に他側の腎の欠損 または腎血拡張を伴う者 2 例となっている。両側性の腎 の障害がないと腎不全の進行はみられない訳であるが。 片側性の変化のみ見られる場合にも残された腎機能を極 力保存し，健側腎が正常に発育し，機能していることを 確認していく必要がある。これらのうち慢性腎血腎炎に みられる変化が VUR と尿路感染のいずれかの原因によ り 2 次的に起きてきたものか，あるいはもともと腎形成 不全が存在していた所に加わって起きてきた変化かは常 
に議論の残る所である、いずれの場合にも腎不全への移 行の予防の試みとしては尿路感染の予防抢よびVURの 治療があげられる、VURも軽度のものは自然消失も充 分望み得るので3)，手術は内科的治療にもかかわらず腎病 変の進行のみられる者, 自然消失の望めない高度の VURのある者に行なっている.このシリーズにおいて手 術を受けた者は片側性疾患 5 例, 両側性疾患 2 例の計 7 例で, 片側性 VUR, UVJ 狭窄に対する尿管膀胱吻合各々 1 例と 2 例，片側性 UPJ 狭窄に対する腎而形成 3 例 (こ の内 1 例は対側腎の欠損を伴っている), そして両側性の 高度の VURに対する両側の尿管膀胱吻合 1 例となって いる。

この最後の患者は偶然の機会に高度の高血圧が見出さ れ, 精査により高度のVURが発見されたが, 血圧のコン トロールも腎不全の予防の大切な要素となっている。外 科的に治療可能な腎血管性の疾患と内科的治療を行う疾 患とに分けられるが，内科的には特別な場合を除いて主 として食塩制限，利尿剤，降圧剤を用いて血圧のコント ロールが試みられる。血尿，蛋白尿の他に高血圧のスク リーニングにより，これら腎尿路系に異常をもつ無症候 性の患者がさらにみつかってくるものと思われる。

最後に慢性系球体腎炎よりの腎不全への進行の予防に ついてみると，現在世界各地でさまざまな治療の試みが なされている。大きく分けてステロイド剤や免疫抑制剤 による治療法と抗凝固剤抢よび抗血小板剤をもちいた治 療法に分けられる。約 10 年で患児の約半数が腎不全へ移 行するといわれる膜性増殖性腎炎に対するステロイド療 法 $^{4}$, その $2 \sim 3$ 割が腎不全に陥るとされている巣状硬化 型ネフローゼ症候群に対するステロイド剤掞よびサイク ロフォスファマイド剤併用の試み，また，アレルギー性 紫斑病腎炎のうち高度の腎炎の所見を示す者に対するサ イクロフォスファマイドによる治療の試みがあげられ る。これらは現在国際小児腎臓病研究班が世界各地のセ ンターより集めた患者において, Double blind study あ るいは Controlled study を試みている，現在進行中の研 究で, 最終的な結論はまだ出ていない ${ }^{5)}$, 急速進行性腎炎
の患者に対するメチルプレドニゾロンの大量静注療法が 試みられ著効を奏している例も報告されている ${ }^{6}$.

腎不全の予防は望み通り行い得ていないのが現状であ るが，我々小児科医は検尿，血圧のチェック，IVP，VCG によるこれらの各疾患の早期発見打よび必要ならば必尿 器科医の診療依頼, さらに尿路感染症の予防と治療, 血 圧のコントロールを常に心掛け, 残されている腎機能を できるだけ長く保っていく様に努力している，慢性腎炎 の治療に対しては様々な試みがなされているが，明解な 治療は見出されていないのが現状である。

\section{文献}

1）飯高喜久雄：小児腎移植の現状と問題点，小児科 20 : 357-363, 1977

2) Winberg J., Larson H., Bergström T.: Comparison of the natural history of Urinary Infection in children with and without vesico-ureteric reflux, Renal infection and renal scarring (Kincaid-Smith P. and Fairley K. F.) : 293-302, Mercedes Publishing Services, Melbturene, 1970.

3) Stephens F. D. : Preliminary follow-up study of 101 chidren with reflux treated conservatively, Renal infection and renal scarring (KincaidSmith P. and Fairley K. F.):283-285, Mercedes Publishing Services, Melbourne, 1970.

4) McAdams A. J., McEnery P. T., West C. D. : Mesangiocapillary glomerulonephritis: changes in glomerular morphology with long-term alternate-day prednisone therapy J. Pediatr:2331, 1975.

5) Personal communication.

6) Davis C. A., McEnery P. T., Maby S., McAdams A. J., West C. D. : Observations on the evolution of idiopathic rapidly progressive glomerulonephritis Clin Nephrol:91-101, 1978. 